\title{
THE INFLUENCE OF DELAY FACTORS ON PAHANG MALAYSIAN CONSTRUCTION INDUSTRY: APLS-SEM APPROACH
}

\author{
Adekunle Qudus Adeleke ${ }^{1 *}$, Ajibike Waliu Adeniyi ${ }^{1}$ and Gerry Nkombo Muuka² \\ 1,2Faculty of Industrial Management, Universiti Malaysia Pahang, Lebuhraya Tun Razak, 26300 Gambang, Pahang, Malaysia \\ ${ }^{2}$ College of Business, Al Ghurair University, Dubai
}

ABSTRACT - Previous research has shown that delay is a common problem in the construction industry. Weather conditions and regulation changes, though being minor factors, are also known as external factors contributing to the delay of project construction. This study involved 118 respondents from the construction industry in Kuantan, Pahang. In order to obtain the data, copies of the questionnaire were distributed widely among people in the Pahang construction industry. The data were analysed by using Partial Least Squares Structural Equation Modelling version 3. A significant positive relationship between weather conditions and building projects in the Pahang construction industry was identified. This study also found a negative relationship between regulation changes and building projects in the Pahang construction industry. As expected, weather conditions were found to be one of the factors contributing to the delay in the process of projects' construction in Malaysia. However, weather conditions and the regulation changes did not significantly affect the construction projects in Malaysia. Out of the factors which contributed to delay in building projects, weather conditions, though a minor factor, played a part in contributing to the extension of the time of the projects in Malaysia. Nevertheless, regulation changes were not considered a vital factor leading to the delay in building projects in Malaysia.
ARTICLE HISTORY

Received: 24-2-2021

Revised: 15-4-2021

Accepted: $20-5-2021$

\section{KEYWORDS}

Delay,

Weather Conditions,

Regulation Changes,

Building Projects,

Construction Industry.

\section{INTRODUCTION}

Sweis et al. (2008) defined delay as an act or situation in which the expected time of delivery or completion of a task is extended in a contractual process. It usually shows up as additional days of work or a setback at the beginning of the activity. Delay occurs in every project but the degree of the delay varies from project to project (Wa'el Alaghbari et al. 2007). Furthermore, according to Sambasivan \& Soon (2007), about $17.3 \%$ of government projects in Malaysia were considered to be sick because they were delayed or abandoned for more than three months. This clearly shows that extension of time of the construction projects exists in Malaysia. Although the delay only occurred for only a few weeks or months, it was still considered a delay as the projects were not completed within the scheduled time.

Consequently, the delay has become a part of the construction industry as it happened frequently. A lot of negative implications occurred due to delay. For instance, the commonest implication was over the budget. Mehdi Riazi \& Lamari (2013) stated that delay caused cost overruns and a bad reputation. Furthermore, there were many factors that caused the delay. Adeleke et al. (2020), Mahamid (2013), and Gilbert (2016) acknowledged that poor weather condition was one of the causes of delay in the construction of projects and it could affect the projects' speed. It could be worsening during a monsoon season in Malaysia as most of the states received rain continuously, especially in the East Coast area in Malaysia. During this monsoon, several places might continuously experience heavy downpours for a few days and this situation might cause a flood.

Moreover, Halpin (2005) reported that weather condition is an uncontrollable factor and it could not be forecasted during contract bidding. Thus, it would be hard to meet the project completion date. As the weather condition is one of the natural occurrences, the projects' stakeholders cannot prevent it from occurring. However, they could minimize the risk of the weather conditions by conducting detailed planning and considering the weather conditions as one of the risks they might face later. In addition, Akanni et al. (2015) stated that operations of construction industries should be covered by planning and environment regulations, codes of practices, safety regulations, licensing, insurance, and taxation laws. Thus, if there are any changes in regulations in the construction of a project, it might affect the time of such a project's completion. In the same vein, Loosemore (2003) reported that problems might arise if there is any change in the regulations.

Therefore, Anslow (2015) stated that risk managers who work in the construction industry should be aware of regulation changes because of the responsibility of creating new obligations for clients, designers, and contractors. The project performer should have active communication with the local authorities so that new updates regarding the new regulations and policies could be known immediately. In many studies, weather conditions and regulation changes were regarded as minor factors that caused the delay in the construction of projects. A lot of people in the construction industry 
do not give sufficient attention to these factors as they thought it would not affect the projects greatly. However, such thought should be reconsidered as many projects in Malaysia were being affected because of the weather conditions and regulatory changes.

\section{LITERATURE REVIEW}

\section{Overview and the Antecedent of Project Delay in Malaysian Construction Industries}

Delay in construction projects is regarded as time and cost overrun outside the scheduled and agreeable completion date with the client and contractor of the project (PRINCE2, 2005). Majority of construction projects in the world suffer time over-run before their actual completion date. For example, the Asian Development Bank project suffered from a nine-month delay and still won an outstanding award. The construction industry has been listed among the top five sectors that contributed to significant rapid growth in the Malaysian economy. Therefore, in order to effectively contribute its quota to the country's economy, a lot of risks need to be avoided in the process of project construction. Delay is one of the risks that the practitioners may face. Troubles may arise because of the delay and it may cause bad relations between all the parties involved in the construction projects. In addition, the cost of the projects may be higher than the budget as time passes (Ahmad Hisham, S., \& Yahya, 2016).

Tumi et al. (2009) reported two types of delay: non-excusable delays and excusable delays. An excusable delay is a form of delay that could not be avoided while the non-excusable delay lies on the contractors or suppliers of the projects. Wa Alaghbari et al. (2007) further reported another type of delay which is known as concurrent delays. This type of delay occurs when more than one factors contribute to the delay in projects at the same time. In addition, according to AlKharashi \& Skitmore (2009), factors that lead to delay in construction projects are external factors such as the weather condition (Albatsh, 2015) and regulation changes (Sambasivan \& Soon, 2007). Malaysian construction industries are not exempted from these challenges of poor performance in time and budget, wastage during construction, low productivity, and over-reliance on foreign labors (Sambasivan \& Soon, 2007). Despite all the challenges, project delay is categorized as the foremost aspect of the construction management process and has become a significant factor towards project success (Azman \& Adeleke, 2018; Hendrickson \& Au, 2008). The study of Azman \& Adeleke (2018) in Malaysia revealed that poor management of plant and machinery, low level of skilled operators, and poor qualified contractor's technical staff were the main causes of project delay because a qualified contractor's technical staff will be able to execute their tasks as expected and project are delivered within the stipulated time.

In the same vein, Anslow (2015) opined that completion of project within the scheduled time is commonly seen as the yardstick towards project success. It was further revealed by the authors that, the National Economic Development Office (NEDO) stated in their report published in 1983 that "a project success is a function of management effort necessary to complete on time and this disciplined approach helped to control quality and cost". This is in line with Ahmed et al. (2003) who affirmed that delays in the project have a significant influence on quality and cost. Thorpe \& Karan, (2008) revealed poor site management and supervision, low speed of decision making involving all project teams, client-initiated variations, necessary variations of works, and inadequate contractor experience as the six most significant factors that lead to delays in civil engineering and building projects. Weather conditions and regulation changes are the independent variables for this study while the dependant variable is building projects in Pahang, Malaysia as previous studies failed to look into these variables from Pahang's point of view. Figure 1 portrays the study's conceptual framework.

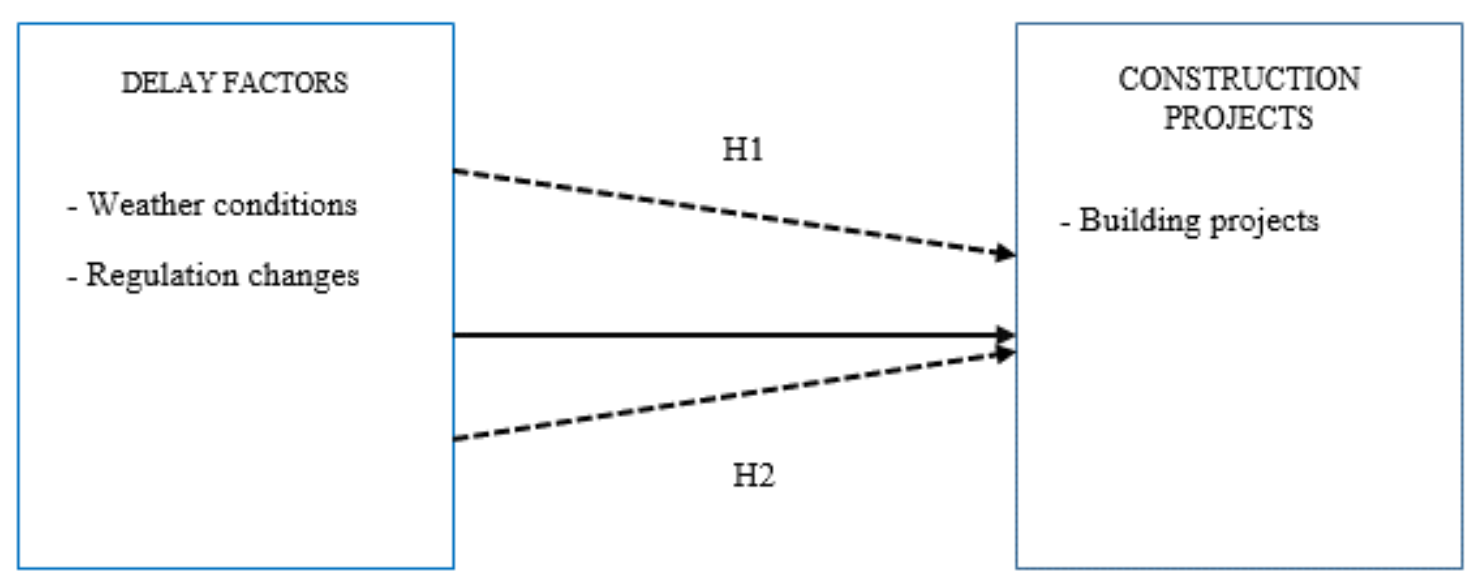

Figure 1. Conceptual model 


\section{Weather Conditions}

Weather condition is an uncontrollable factor as it is an Act of God or also known as Force Majeure. Thorpe \& Karan (2008) identified that the weather condition is a significant cause of delay in the construction industry. However, Jang et al. (2008) mentioned that it varies depending on the exact location and the time of the construction work. This indicates that the weather conditions might give different implications to different projects which are situated at different locations and executed at different times. The effect of the weather conditions on building projects in Europe varies compared to building projects in Asia as the temperature and the weather conditions in these two locations are different.

On the other hand, Aziz (2013) reported that extreme weather condition was one of the least important causes of delay. This was also supported by Sambasivan \& Soon (2007) who ranked weather condition among the lowest factors leading to delay. Thus, it could be seen that the effect of the weather conditions on the building projects varies. It might greatly affect the building projects, but it might not have any consequence on the building projects.

Hypothesis 1: There is a significant relationship between weather conditions and building projects in the Pahang construction industry.

\section{Regulation Changes}

Uher \& Loosemore (2004) mentioned that projects are usually influenced by regulatory control. This means all projects have to follow all rules and regulations which include internal and external regulations. Internal regulations are rules made by the organization while external regulations are rules made by the government. Therefore, Sun \& Meng (2009) and Chang et al. (2011) stated that legislative or policy changes would contribute to changing orders in a project. Doloi et al. (2012) reported that communication between project performers and local authorities is important to prevent the project performance from being affected. In addition, Anslow (2015) stated that managers in the construction industry should be aware of any changes in regulations. It could be said that the awareness of people in the construction industry regarding rules and regulations changes is important as it might affect the projects in various aspects such as project performance, order of tasks and activities, duration, and cost of the projects.

Hypothesis 2: There is a significant relationship between regulation changes and building projects in the Pahang construction industry.

\section{Relationship between Weather Conditions and Building Projects}

Many researchers ranked weather conditions at the lowest level of the factors that cause a delay in the construction project. According to Aziz (2013), the extreme weather condition is one of the least important causes of delay. However, Jang et al. (2008) and Migliaccio et al. (2013) stated that the impacts of the weather condition depend on a project's exact location. Othman et al. (2006) added that it also varies based on the time the work is executed.

According to Thorpe \& Karan (2008), the weather condition is a significant factor that causes a delay in the construction project. Moreover, Aziz (2013), Marzouk \& El-Rasas (2014), Assaf \& Al-Hejji (2006) also listed weather conditions as one of the contributors to delay. As weather conditions cannot be foreseen or predicted, the stakeholders involved in the project do not have control over it. Therefore, this study revealed a negative relationship between the weather condition and building projects.

There are five processes that are involved in the project life cycle. They are initiating phase, planning phase, executing phase, controlling and monitoring phase, and closing phase (PMBOK guide, 2004). It is important to identify weather conditions as one of the risks and then to prepare risk response planning during the planning phase. This is because weather condition affects the building project the most during the executing phase. The effects vary based on the type of weather at that particular time. Crissinger (2005) reported that hot and dry conditions affect the site's air environment, concrete and mortar strengths, and poor bond of bricks. Besides, wet weather condition affects the site work, groundwater, bricks, fibrous and porous products, paint, and building performance.

\section{Relationship between Regulation Changes and Building Projects}

According to Aziz (2013), change of regulations and laws is one of the least important causes of delay. On the contrary, many researchers like Ahmed et al. (2003) and Chung et al. (2020) listed regulation and law changes as the main cause of delay in building projects. The studies show a negative relationship between the regulation changes and building projects. It is uncommon for the regulations and laws to change abruptly, so the contractors do not have a problem with it. However, when there is a change in the regulations and laws, and the contractors are not aware of it; then it will cause serious problems in the future.

A lot of building projects have gone through the process where their designs keep changing. Regulation changes have been known as one of the major factors responsible for delays in building projects. However, one of the reasons for this change is caused by the regulations and laws change. Sun \& Meng (2009), Chung et al. (2020), Wu et al. (2005) and Kanimoli et al. (2020) recognized regulation and law changes as critical factors that have been contributing to changes in 
project's design. Thus, it shows that changes of regulation and law changes are part of the root causes of project delay and it shows a negative relationship between the regulation changes and building projects as well.

\section{Research Objectives}

To address the aforementioned issues, this paper aims to provide answers to the following objectives.

1) To identify the relationship between weather conditions and building projects in the Pahang construction industry;

2) to examine the relationship between regulation changes and building projects in the Pahang construction industry.

\section{METHODOLOGY}

This study adopted a cross-sectional research design. Data were collected at a single point-in-time using a structured questionnaire (Sekaran \& Bougie, 2016). A proportionate stratified random sampling technique was also employed in this study. The study employed a quantitative approach as it is mostly adopted in the social sciences (Kanimoli et al., 2020; Sekaran et al., 2001).

\section{Instrument Design}

According to Monette et al. (2013), one of the methods in collecting data for survey research is the use of a questionnaire. The questionnaire contains items that would be answered by the respondents without the assistance of an interviewer. In this study, most of the items in the questionnaire were adapted and modified from previous studies. The questionnaire for this study adopted a five-point Likert scale. The adopted rating scale is as follows: 1 - 'strongly disagree', 2 - 'somewhat disagree', 3 - 'neither agree nor disagree', 4 - 'somewhat agree', and 5 - 'strongly agree' (Omer \& Adeleke, 2019). This study was conducted among people in the construction industry in Kuantan, Pahang in 2018.145 copies of the questionnaire were distributed to people in the Pahang construction industry. The total number of respondents for this study was 118 respondents including project managers, contractors, architects, engineers, and others. The copies of the questionnaire distributed were collected by self- administered, Google Form, and dropped and picked. After the data was collected, the data was analysed by using SmartPLS 3. It measured both the dependent and independent variables of this study (Samsudin et al., 2020).

Table 1. Source Of Measurement

\begin{tabular}{lllll}
\hline S/N & Construct & Dimension & Source & Remarks \\
\hline 1 & Delay & Weather Conditions & Sambasivan And Soon (Sambasivan & Adapted \\
& & Regulatory Changes & \&oon, 2007) & \\
\hline
\end{tabular}




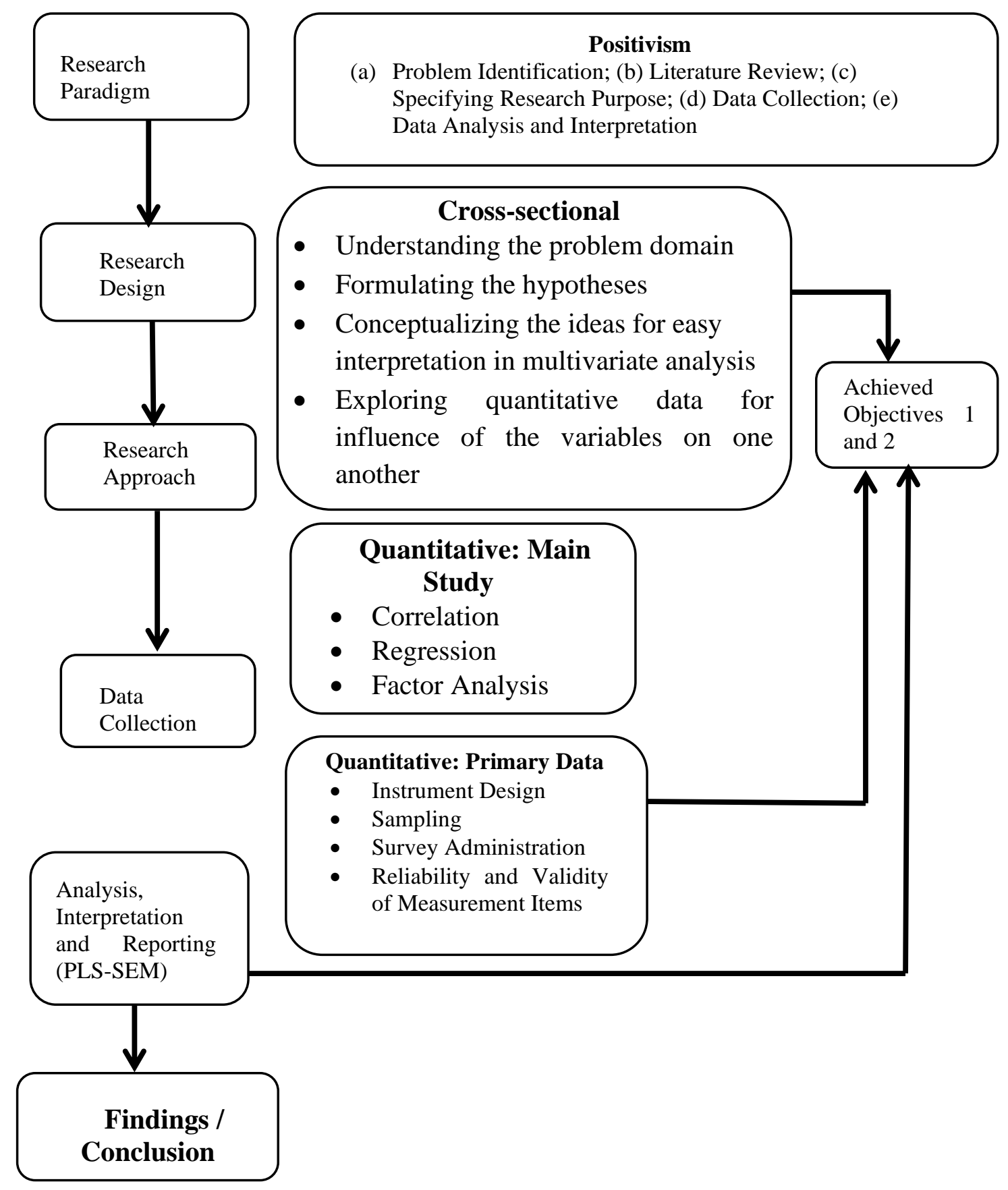

Figure 2. Research Methodology Flow Chart

\section{RESULTS AND DISCUSSION}

\section{Data Collection and Sample}

145 copies of the questionnaire were distributed among people in the construction industry in Pahang. The response rate was $81.38 \%$ and the acceptable sample size for this study was 118 . Table 2 below shows the summary of respondents' profiles. 
Table 2. Summary Of Respondent Profile

\begin{tabular}{|c|c|c|c|}
\hline Type & Items & Frequency $(\mathbf{N})$ & Percentage $(\%)$ \\
\hline \multirow[t]{6}{*}{ Job Position } & Contract Manager & 3 & 2.50 \\
\hline & Project Manager & 26 & 22.0 \\
\hline & Architect & 9 & 7.6 \\
\hline & Engineer & 18 & 15.3 \\
\hline & Contractor & 32 & 27.1 \\
\hline & Others & 30 & 25.4 \\
\hline \multirow[t]{4}{*}{ Working Experience Range } & 1-3 Years & 21 & 17.8 \\
\hline & 4-6 Years & 47 & 39.8 \\
\hline & 7-9 Years & 33 & 28.0 \\
\hline & $>10$ Years & 17 & 14.4 \\
\hline \multirow[t]{2}{*}{ Gender } & Male & 81 & 68.6 \\
\hline & Female & 37 & 31.4 \\
\hline \multirow[t]{2}{*}{ Organization Ownership } & Local & 107 & 90.7 \\
\hline & National & 11 & 9.3 \\
\hline \multirow[t]{4}{*}{ Company Location } & Local Market Area & 43 & 36.4 \\
\hline & Within Few States & 58 & 49.2 \\
\hline & Across Malaysia & 15 & 12.7 \\
\hline & International Market & 2 & 1.7 \\
\hline \multirow[t]{4}{*}{ Organization Existence Range } & 1-3 Years & 2 & 1.7 \\
\hline & 4-6 Years & 12 & 10.2 \\
\hline & 7-9 Years & 51 & 43.2 \\
\hline & $>10$ Years & 53 & 44.9 \\
\hline \multirow[t]{5}{*}{ Number Of Employees } & $0-30$ & 38 & 23.2 \\
\hline & $31-60$ & 26 & 22.0 \\
\hline & $61-90$ & 15 & 12.7 \\
\hline & $91-120$ & 13 & 11.0 \\
\hline & $>120$ & 26 & 22.0 \\
\hline \multirow[t]{5}{*}{ Organization Specialization } & Commercial Building & 28 & 23.7 \\
\hline & Residential Building & 66 & 55.9 \\
\hline & Civil Building & 4 & 3.4 \\
\hline & Industrial Building & 8 & 6.8 \\
\hline & Educational Building & 12 & 10.2 \\
\hline
\end{tabular}

\section{Measurement Model}

According to Ishak et al. (2020), content validity refers to the extent to which the items in a research instrument can cover the supposed measured content. It is essential because it would help in constructing validity. Table 3 shows the content validity of the applied measure. This table explains that each construct has its high loading when it is related to other constructs. Next, the loading of the items was considerably done on their respective constructs to ensure the content validity of this study (Chow \& Chan, 2008; Subani et al., 2020).

Table 3. Factor Analysis And Loading Of The Items (Cross Loading)

\begin{tabular}{cccc}
\hline Items & Building Projects & Regulation Changes & Weather Conditions \\
\hline Bp10 & 0.795 & 0.275 & 0.320 \\
Bp2 & 0.810 & 0.285 & 0.344 \\
Bp3 & 0.779 & 0.388 & 0.395 \\
Bp7 & 0.744 & 0.262 & 0.282
\end{tabular}




\begin{tabular}{cccc}
\hline Items & Building Projects & Regulation Changes & Weather Conditions \\
\hline Bp8 & 0.811 & 0.361 & 0.405 \\
Bp9 & 0.801 & 0.337 & 0.406 \\
Rc1 & 0.236 & 0.713 & 0.589 \\
Rc11 & 0.316 & 0.719 & 0.616 \\
Rc12 & 0.377 & 0.774 & 0.670 \\
Rc14 & 0.320 & 0.732 & 0.562 \\
Rc2 & 0.313 & 0.702 & 0.587 \\
Rc3 & 0.284 & 0.779 & 0.613 \\
Rc4 & 0.208 & 0.650 & 0.558 \\
Rc8 & 0.266 & 0.742 & 0.593 \\
Wc1 & 0.239 & 0.607 & 0.691 \\
Wc10 & 0.307 & 0.449 & 0.592 \\
Wc1 & 0.354 & 0.591 & 0.761 \\
Wc12 & 0.252 & 0.576 & 0.689 \\
Wc13 & 0.299 & 0.675 & 0.706 \\
Wc3 & 0.271 & 0.570 & 0.684 \\
Wc4 & 0.403 & 0.630 & 0.809 \\
Wc5 & 0.455 & 0.655 & 0.782 \\
Wc7 & 0.269 & 0.540 & 0.675 \\
\hline
\end{tabular}

Convergent validity is known to be the extent to which a group of variables converged in assessing a specific concept. Table 4 and Figure 2 show all the items that were analysed. It included Average Variance Extracted (AVE), factor loading, and composite reliability. In convergent validity, more than one item would be measured as it extends in a similar notion. The value of AVE must exceed 0.5. In addition, Composite Reliability (CR) was used to assess the convergent validity. It is referred to as the degree to which a set of items frequently show the latent construct (Taofeeq et al., 2020).

Table 4. Convergent Validity Table

\begin{tabular}{|c|c|c|c|c|}
\hline Construct & Item & Loading & Ave & $\mathrm{Cr}$ \\
\hline \multirow[t]{6}{*}{ Building Project } & Bp10 & 0.795 & 0.625 & 0.909 \\
\hline & Bp2 & 0.810 & & \\
\hline & Bp3 & 0.779 & & \\
\hline & Bp7 & 0.744 & & \\
\hline & Bp8 & 0.811 & & \\
\hline & Bp9 & 0.801 & & \\
\hline \multirow[t]{8}{*}{ Regulation Changes } & Rc1 & 0.713 & 0.529 & 0.900 \\
\hline & Rc11 & 0.719 & & \\
\hline & Rc12 & 0.774 & & \\
\hline & Rc14 & 0.732 & & \\
\hline & $\mathrm{Rc} 2$ & 0.702 & & \\
\hline & Rc3 & 0.779 & & \\
\hline & $\mathrm{Rc} 4$ & 0.650 & & \\
\hline & Rc8 & 0.742 & & \\
\hline \multirow[t]{9}{*}{ Weather Condition } & Wc1 & 0.691 & 0.508 & 0.902 \\
\hline & Wc10 & 0.592 & & \\
\hline & Wc11 & 0.761 & & \\
\hline & Wc12 & 0.689 & & \\
\hline & Wc13 & 0.706 & & \\
\hline & Wc3 & 0.684 & & \\
\hline & Wc4 & 0.809 & & \\
\hline & Wc5 & 0.782 & & \\
\hline & Wc7 & 0.675 & & \\
\hline
\end{tabular}

According to Malik \& Adeleke (2018), discriminant validity is essential before analyzing the hypothesis test. The value of the test showed the extent to which items vary among constructs. Table 5 shows the values for discriminant validity. 
Table 5. Discriminant Validity

\begin{tabular}{cccc}
\hline Items & Building Project & Regulation Changes & Weather Condition \\
\hline Building Project & 0.790 & & \\
Regulation Changes & 0.409 & 0.727 & \\
Weather Condition & 0.461 & 0.825 & 0.713 \\
\hline
\end{tabular}

After completing the discriminant validity test, hypothesized relationships among variables could be tested. Figure 3 shows the illustrated path coefficient of this study.

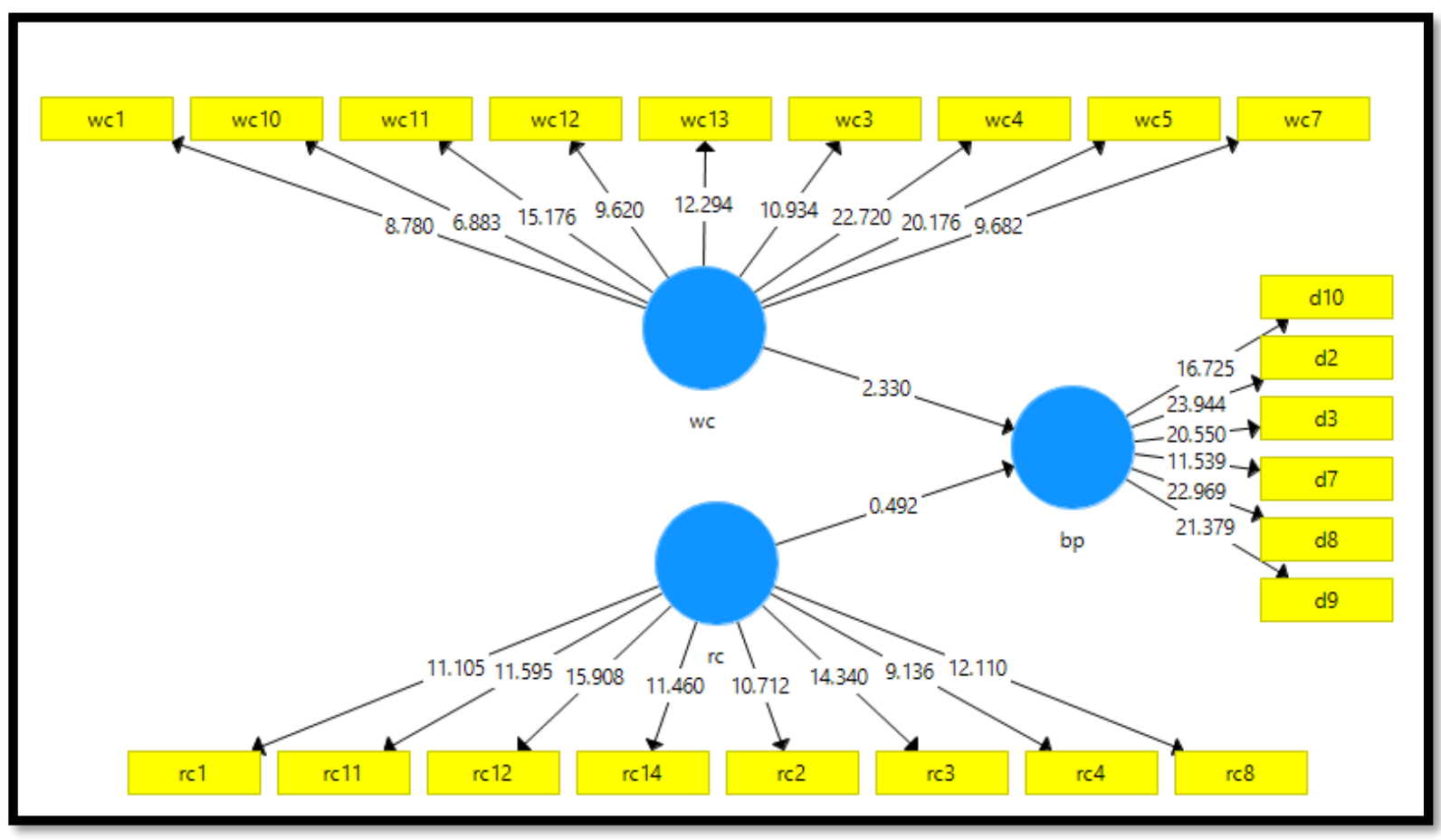

Figure 3. Path Model Significant Result

Table 6 below shows the results of the hypothesis testing. Weather condition had a significant effect on building projects $(\beta=0.166, t=2.330, p=0.020)$. Therefore, hypothesis 1 was supported. The test result for regulation changes had no significance on building project $(\beta=0.181, \mathrm{t}=0.492, \mathrm{p}=0.623)$. Thus, hypothesis 2 which was a factor of delay was not supported.

This study shows that the people in the construction industry in Kuantan, Pahang did not agree that regulation changes could lead to delay in building projects. However, they agreed that weather conditions factor could contribute to delay in building projects.

Table 6. The Result Of Inner Structure Model

\begin{tabular}{lllllll}
\hline Hypothesis & Variables & B & Se & T/V & P/V & Findings \\
\hline H1 & $\begin{array}{l}\text { Weather } \\
\begin{array}{l}\text { Conditions } \\
\text { Regulation } \\
\text { H2 }\end{array}\end{array}$ & 0.387 & 0.166 & 2.330 & 0.020 & Supported \\
& 0.089 & 0.181 & 0.492 & 0.623 & $\begin{array}{l}\text { Not } \\
\text { Supported }\end{array}$ \\
\hline
\end{tabular}

Cohen (1988) suggested that the effect size's criteria must be less than $0.02(0.02=$ small, $0.15=$ medium, $0.35=$ high $)$. Table 7 indicates that weather conditions contributed a small part to the delay in the Pahang construction industry while regulation changes did not have any contribution to delay in building projects in the Pahang construction industry. 
Table 7. Direct Effect Iv-Dv

\begin{tabular}{lllll}
\hline R-Squared & Included & Excluded & F-Squared & Effect Size \\
\hline $\begin{array}{l}\text { Weather } \\
\begin{array}{l}\text { Conditions } \\
\text { Regulation }\end{array}\end{array}$ & 0.215 & 0.168 & 0.599 & Small \\
Changes & 0.215 & 0.168 & 0.0038 & None \\
\hline
\end{tabular}

This study used SmartPLS as the analysis technique. The measuring of the study's data was carefully done before testing the research's model in order to find the reliability and validity of the outer model. Thus, the relationships of the hypothesis were assessed. After measuring the hypothesis test, the predictive power of the model was measured. The last step involved the assessing of the structural model and the results were given in detail.

Table 8. Summary Of The Results

\begin{tabular}{clc}
\hline Hypothesis & \multicolumn{1}{c}{ Hypothesis Path } & Decision \\
\hline H1 & Weather Conditions As A Delay & Supported \\
& Factor Has A Significant Effect On & \\
& Building Projects. & \\
Regulation Changes As A Delay & Factor Has A Significant Effect On & Not Supported \\
& Building Projects. & \\
\hline
\end{tabular}

\section{CONCLUSION}

This study is limited to building projects in the construction industry. Thus, future researchers might investigate more about the delay on other projects like road projects, bridge projects, and others. Moreover, further studies in the construction industry should focus on other factors that contribute to the delay. Moreover, the results in Section 4 show that the indicators for both constructs were properly measured with their respective constructs as seen in their statistical significance and parameter estimates.

\section{LIMITATION OF THE STUDY AND FUTURE RESEARCH DIRECTIONS}

Although this research has affirmed support for a few hypothesized relationships between the exogenous and endogenous variables, the results need to be interpreted with the condition to the study limitations. Firstly, the current study makes use of a cross-sectional design that does not give room for underlying illations to be established from the study population. Therefore, a longitudinal design might be considered in the future for assessing the theoretical constructs at a different point in time to ascertain the findings of the current study.

Similarly, this study employs a proportionate stratified random sampling which shows that the population elements were randomly picked within one state in Malaysia, as such, the level to which sample size characterizes the entire population was selected randomly. Hence, future studies might go further by investigating more than a state in Malaysia.

\section{ACKNOWLEDGEMENT}

The authors would like to thank UMP for funding this work under an internal grant RDU190390.

\section{REFERENCES}

Adeleke, A.Q., Nawi, M.N.M. \& Abd-Karim, S.B. (2020). Where are we? The level of risk management in Malaysian construction industries, Int. J Sup. Chain. Mgt, 9, 527.

Ahmed, S.M., Azhar, S., Kappagntula, P. \& Gollapudil,D. (2003). Delays in construction: a brief study of the Florida construction industry, in: Proc. 39th Annu. ASC Conf. Clemson Univ. Clemson, SC, 2003: p. 66.

Akanni, P.O., Oke, A.E. \& Akpomiemie, O.A. (2015). Impact of environmental factors on building project performance in Delta State, Nigeria. HBRC J. 11, 91-97.

Alaghbari, W., Kadir, M.R.A. \& Salim, A. (2007). The significant factors causing delay of building construction projects in Malaysia. Eng. Constr. Archit. Manag. 14, 192-206. https://doi.org/10.1108/09699980710731308. DOI.10.1108/09699980710731308.

Albatsh, N.J. (2015). Assessment of delay causes of construction projects in Palestine.

Al-Kharashi, A. \& Skitmore, M. (2009). Causes of delays in Saudi Arabian public sector construction projects. Constr. Manag. Econ. 27, 3-23.

Anslow, J. (2015). New regulations are changing the construction industry. https://www.insurancetimes.co.uk/new-regulations-arechanging-the-construction- industry/1414147.

Assaf, S.A. \& Al-Hejji, S. (2006). Causes of delay in large construction projects. Int. J. Proj. Manag. 24, 349-357.

Aziz, R.F. (2013). Ranking of delay factors in construction projects after Egyptian revolution, Alexandria Eng. J. 52, $387-406$.

Azman, N.A.M. \& Adeleke, A.Q. (2018). Effect of Time Overruns on Apartment Building among Kuantan Malaysian Construction Industries. J. Adv. Res. Appl. Sci. Eng. Technol. 10, 41-47. 
Chang, A.-T., Shih, J.S. \& Choo, Y.S. (2011). Reasons and costs for design change during production. J. Eng. Des. 22 (275-289.

Chow, W.S. \& Chan, L.S. (2008). Social network and shared goals in organizational knowledge sharing.

Chung, R.M. , Adeleke, A.Q. \& Ajibike, W.A. (2020). Client Delay Factors Affecting Building Project Performance Among Kuantan Malaysian Construction Industry: Through Partial Least Square Structural Equation Modeling. Econ. Res. 4 (2020).

Cohen, J. (1988). Statistical power analysis for the behavioral sciences (Revised ed.). Lawrence Earlbaum Associates.

Crissinger, J. (2005). Design And Construction vs. Weather (pp. 20-24). http://rci-online.org/wp-content/uploads/2016/04/2005-02crissinger.pdf., (2005).

Doloi, H., Sawhney, A., Iyer, K.C. \& Rentala, S. (2012). Analysing factors affecting delays in Indian construction projects, Int. J. Proj. Manag. 30, 479-489.

Gilbert, J. (2016). Heavy rain causing construction delays. Newsplex.com. http://www.newsplex.com/home/headlines/Heavy-RainCausing- Construction-Delays- 370028201.html.

Halpin, D. (2005). Construction Management. 3rd Ed.. Wiley.

Hendrickson, C., \& Au, T. (2008). Project management for construction. Carnegie Mellon University., (2008).

Ishak, S.I. , Adeleke, A.Q. \& Bamgbade, J.A. (2020). Emperical Evidenece on Construction Waste Management among Kota Bharu Malaysian Construction Industry: a PLS-SEM Approch. Econ. Res. 4.

Jang, M.-H., Yoon, Y.-S., Suh, S.-W. \& Ko, S.-J. (2008). Method of using weather information for support to manage building construction projects, in: AEI 2008 Build. Integr. Solut. pp. 1-10.

K. Ahmad Hisham, S., \& Yahya, Causes And Effects of Delays In Construction Industry. Civil.utm.my. Retrieved 22 February 2018 , from http://civil.utm.my/wpcontent/uploads/2016/12/Causes-and-Effects-of-Delays-in- Construction-Industry.pdf., (2016).

Kanimoli, A., Adeleke, A.Q. \& Taiwo, T. T.(2020). Organizational Structure Influence On Construction Waste Management Among Penang Malaysian Construction Industry: An Approach Via Partial Least Square Structural Equation Modeling. https//Www. Jobmer. Org. 4.

Loosemore, M. (2003). Essentials of construction project management. UNSW Press.

Mahamid, I. (2013). Contractors perspective toward factors affecting labor productivity in building construction, Eng. Constr. Archit. Manag.

Malik, N.S.A. \& Adeleke, A.Q. (2018). The Effect of Organizational Culture on Material Risk among Malaysian Construction Industries. J. Adv. Res. Appl. Sci. Eng. Technol. 10, 34-40.

Marzouk, M. M. \& El-Rasas, T. S. (2014). Analyzing delay causes in Egyptian construction projects. J. Adv. Res. 5. 49-55.

Mehdi Riazi, S.R. \& Lamari, F. (2013). Public sector project delay: the Malaysian perspective and the way forward, in: Proc. 19th CIB World Build. Congr. Brisbane 2013 Constr. Soc., Queensland University of Technology, 2013.

Migliaccio, L., Guindani, G. C., D'Incognito, M., and Zhang. (2013). Empirical assessment of spatial prediction methods for location cost adjustment factors. Journal of Construction Engineering and Management, Vol. 139 No. 7, pp. 858-869.

Monette, D.R., Sullivan, T.J. \& C.R. DeJong, C. R. (2013). Applied social research: A tool for the human services. Nelson Education.

Omer, M.S. \& Adeleke, A.Q. (2019). Systematic Critical Review of Risk Management in Malaysian Construction Companies. $J$. Humanit. Soc. Sci. Stud. 1.

Othman, A.A., Torrance, J.V. \& Hamid, M. A. (2006). Factors influencing the construction time of civil engineering projects in Malaysia, Eng. Constr. Archit. Manag.

PMBOK guide, Project Management Institute. (2004). A guide to the project management body of knowledge (PMBOK guide) (3rd ed.). Newtown Square, Pa.: Project Management Institute., (2004).

PRINCE2, Managing successful projects with PRINCE2. (2005) (4th ed., pp. 7-19). London., (2005).

S.A.H. Tumi, A. Omran, A.H.K. Pakir, Causes of delay in construction industry in Libya, in: Int. Conf. Econ. Adm., 2009: pp. 265272.

Sambasivan, M. \& Soon, Y.W. (2007). Causes and effects of delays in Malaysian construction industry, Int. J. Proj. Manag. 25 517526.

Samsudin, N.S.A. , Adeleke, A.Q. \& Ajibike, W.A. (2020). Effects of Contractors' Delay Factors on Building Project Performance Among Kuantan Malaysian Construction Industry. Soc. Sci. Humanit. J. 1705-1715.

Sekaran, U. \& Bougie, R. (2016). Research methods for business: A skill building approach, John Wiley \& Sons, 2016.

Sekaran, U., Robert, Y. C., \& Brain. (2001). Applied business research.1st edition. John Wiley \& Sons Australian Ltd., (2001).

Subani, N.A. , Adeleke, A.Q. \& Bamgbade, J.A. (2020). The Role of Organizational Culture on Sustainable Construction among Malacca Malaysian Construction Industry: A Partial Least Square Approach. Soc. Sci. Humanit. J. 1681-1692.

Sun, M. \& Meng, X. (2009). Taxonomy for change causes and effects in construction projects. Int. J. Proj. Manag. $27,560-572$.

Sweis, G., Sweis, R., Hammad, A.A. \& Shboul, A. (2008). Delays in construction projects: The case of Jordan, Int. J. Proj. Manag. $26,665-674$.

Taofeeq, D.M. , Adeleke, A.Q. \& Ajibike, W.A. (2020). Human Factors Influencing Contractors' Risk Attitudes : A Case Study of the Malaysian Construction Industry Keywords. Constr. Econ. Build. 20 , 96-116. https://doi.org/10.5130/AJCEB.v20i1.6735. DOI.10.5130/AJCEB.v20i1.6735.

Thorpe, D. \& Karan, E.P. (2008). Method for calculating schedule delay considering weather conditions, in: Proc. 24th Annu. Conf. Assoc. Res. Constr. Manag. (ARCOM 2008), Association of Researchers in Construction Management (ARCOM), 2008: pp. 809-818.

Uher, T. \& Loosemore, M. (2004). Essentials Of Construction Project Management (1st ed.).University of New South Wales Press Ltd..

Wu, C., Hsieh, T. \& Cheng, W. (2005). Statistical analysis of causes for design change in highway construction on Taiwan. Int. J. Proj. Manag. 23, 554-563.

\section{CONFLICT OF INTEREST}

There is no potential conflict of interest reported by the authors. 


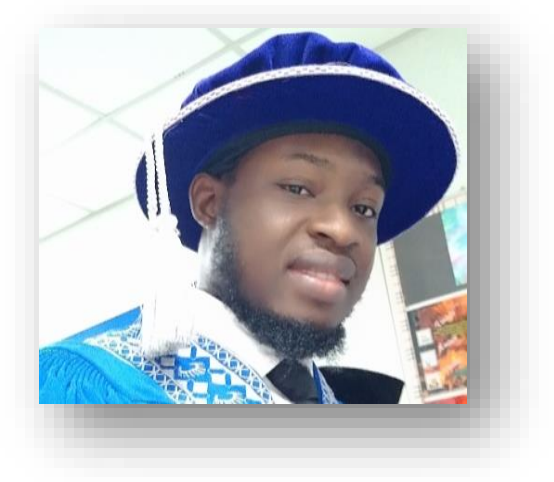

Adekunle Qudus Adeleke is a senior lecturer of Project Management at the Faculty of Industrial Management, Universiti Malaysia Pahang, Malaysia. He is a professional member of the Malaysian Institute of Management (M.I.M) and a member of the Association of Construction Project Managers (ACPM), Malaysia. His primary research activities involve the area of Project Management (e.g., Risk Management in Construction Project, IR 4.0 Related Issues in Construction, Organizational Control, Sustainability in Construction Project, Waste Management in Construction Project, Business Management and Ethics, Quantitative and Qualitative research experts).

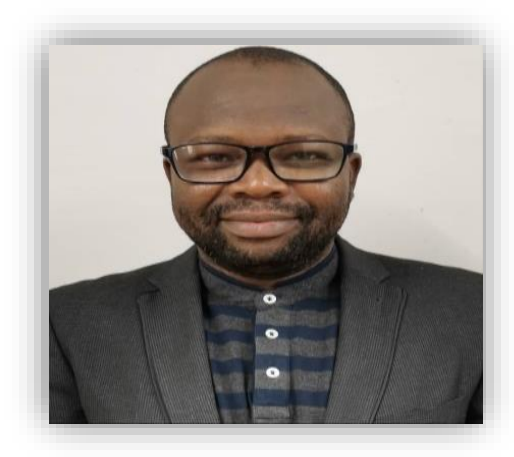

Ajibike Waliu Adeniyi is a Ph.D. candidate in project management at the Faculty of Industrial management, Universiti Malaysia Pahang, Malaysia. He holds Master's in Sustainable Development Practice from the University of Ibadan, Nigeria with much focus on economic sustainability. His main research interest centers on environmental sustainability and how it can be integrated into the construction projects.

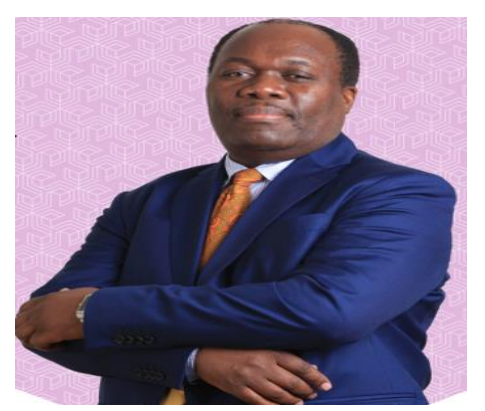

Gerry Nkombo Muuka is Professor of Strategic Management and an active Dean of College of Business Al Ghurair University, Dubai, United Arab Emirates. Prof. Muuka was the director for AACSB Accreditation at Murray State University, KY, the USA from 2016 to 2018. He has rendered several consultation services on Corporate Strategy and as well as Business School Accreditation. His research areas include and not limited to Strategic Management, Business Management and AACSB Accreditation. 